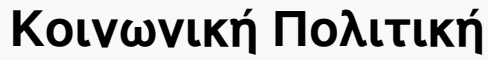

Tóp. 6 (2016)

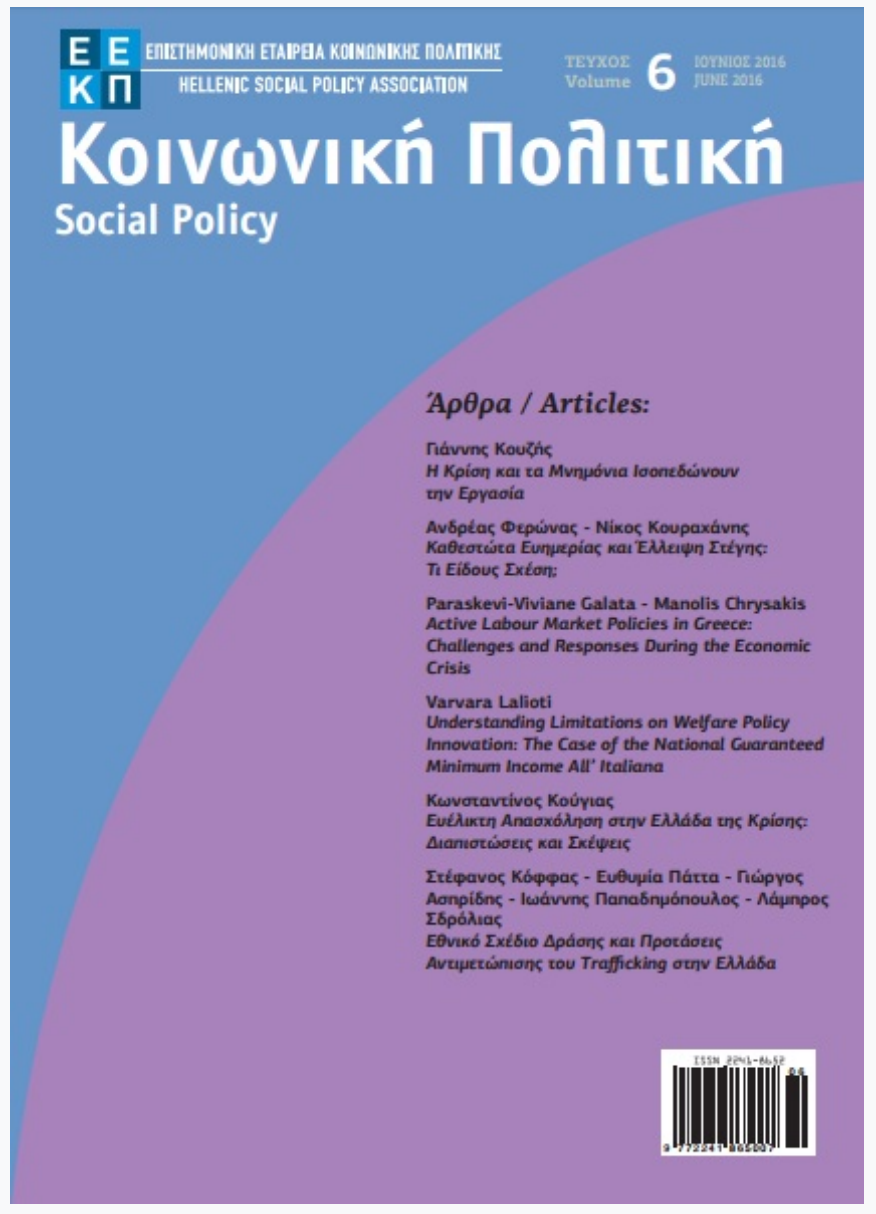

\section{Understanding Limitations on Welfare Policy Innovation: The Case of National Guaranteed Minimum Income All Italiana}

\section{Varvara Lalioti}

doi: $\underline{10.12681 / \mathrm{sp} .10881}$

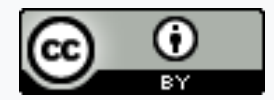

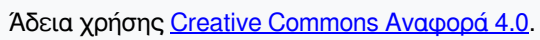

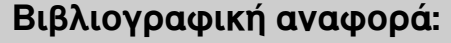

Lalioti, V. (2017). Understanding Limitations on Welfare Policy Innovation: The Case of National Guaranteed Minimum

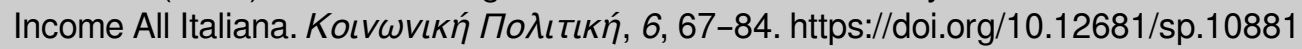




\title{
Understanding Limitations ON Welfare PoliCy InNOVATION: \\ The Case of the National Guaranteed Minimum InCome all' \\ ITALIANA
}

Dr Varvara Lalioti

Postdoctoral Researcher,

Panteion University of Social and Political Sciences

\begin{abstract}
At the beginning of 2016, Italy remained one of the very few Eurozone countries without a national-level Guaranteed Minimum Income (GMI), arguably a major lacuna in the armoury of the welfare state at a time of severe crisis and significant public spending cuts. Drawing on personal communications, parliamentary archives and secondary sources, an actor-centred approach emphasizing the role of domestic actors such as parties, trade unions and religious organizations is utilized to discuss the chronicle of the Italian GMI experience; especially the experimental national GMI in the late 1990s and the early 2000s.

The experiment met with an early demise due to a meagre support base, in conjunction with the dominance of northern interests at the ministry responsible for the design and implementation of a scheme that mainly benefited the poorer south. A policy targeting 'outsiders' and introduced without broad consensus among key policy actors is unlikely to be durable. The recent economic crisis has revived the debate, as old and new policy actors express support for national-level GMI.
\end{abstract}

Keywords: guaranteed minimum income; Italy; actor-centred approach

\section{Пєрі́ $\eta \psi \eta$}

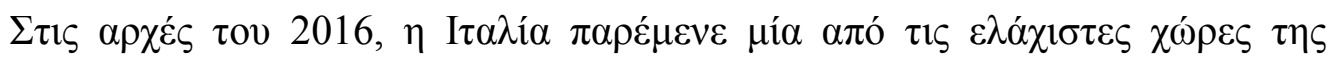

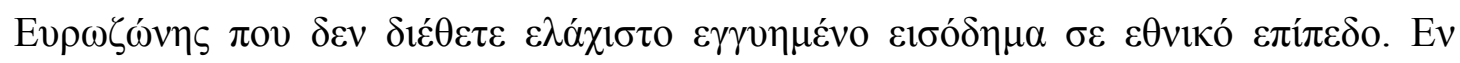

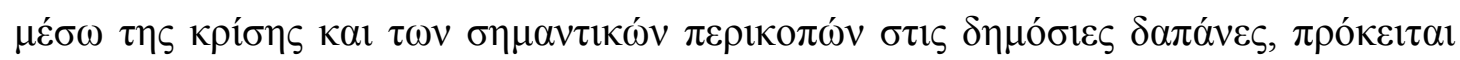

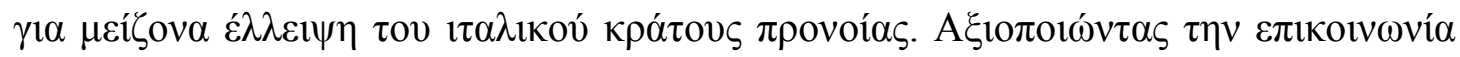

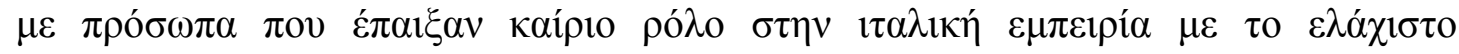

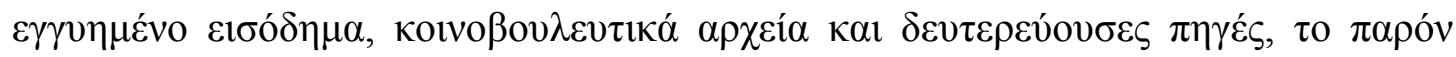




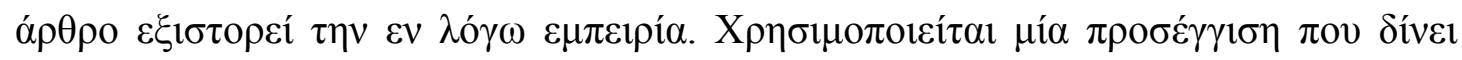

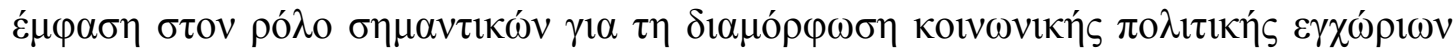

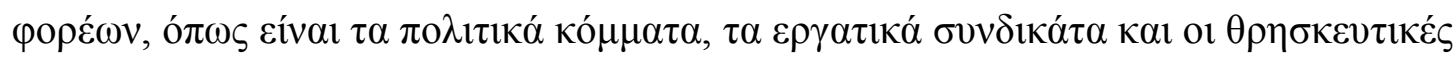

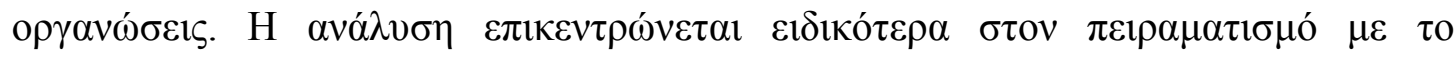

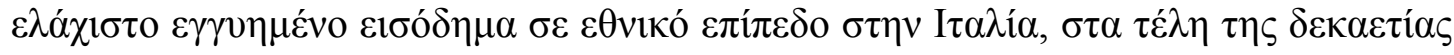
$1990 \kappa \alpha \imath \tau 1 \varsigma \alpha \rho \chi \varepsilon ́ \varsigma \tau \eta \varsigma \delta \varepsilon \kappa \alpha \varepsilon \tau i ́ \alpha \varsigma 2000$.

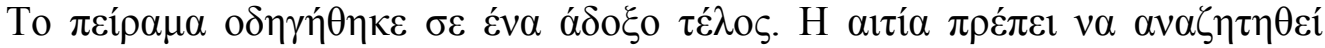

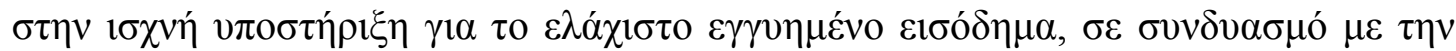

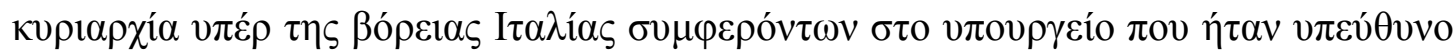

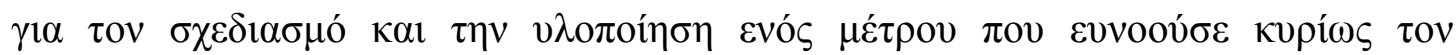

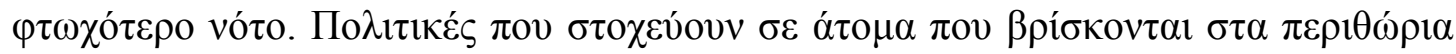

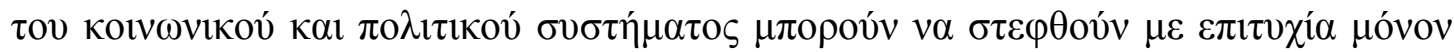

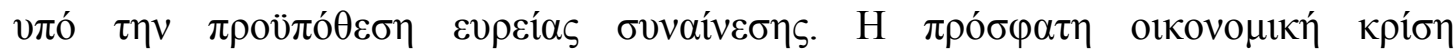

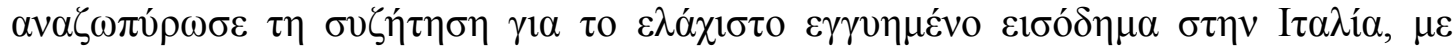

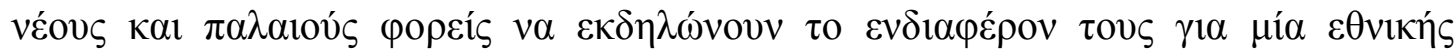
$\varepsilon \mu \beta \varepsilon ́ \lambda \varepsilon i \alpha \varsigma \varepsilon \varphi \alpha \rho \mu о \gamma \eta ́$.

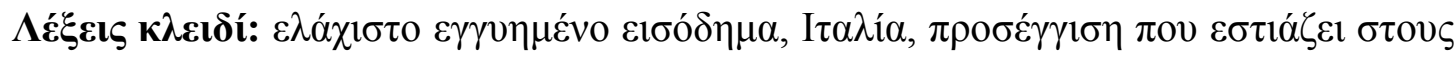

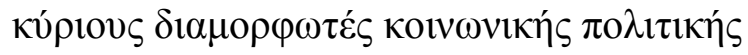

\section{Introduction}

The Guaranteed Minimum Income (GMI) is an instrument of the 'third generation' of social assistance schemes. These are distinguished mainly by the combination of monetary allowances with social insertion measures (Kazepov, 2011:106). Payments usually cover the difference between a household's actual income and the resources it needs, according to a defined standard for living in a specific region or country. Recipients are required to participate in social insertion programmes meant to facilitate job-market integration, such as vocational training programmes (Matsaganis, 2013: 16, 21-22).

EEC recommendations issued in 1992 advocated common criteria on sufficient resources and social assistance and convergence of social protection objectives and policies. Following this, the political and intellectual climate in most EEC member states turned toward the establishment of national-level GMI schemes. 
At the beginning of $2016^{1}$, Italy remained one of the very few Eurozone countries still lacking a permanent, national GMI.

Italy launched a national GMI experimentally in 1998, only to abandon it a few years later. Other national, regional and local programmes against poverty have been developed, but do not substitute for a national GMI. A relatively delayed and unclear framework of social assistance decentralization has largely contributed to extremely uneven development and non-generalized adoption of these schemes by Italian regions and municipalities. Additionally, the sub-national schemes depend on resource availability and do not constitute individual enforceable rights (Lalioti, 2013: 126, 133-135; Madama, Jessoula and Natili, 2014: 16-18, 25, 27).

Notorious for high spending on old-age benefits ${ }^{2}$, the Italian welfare state is known for paying limited attention to 'outsiders'. Aggregate spending on the two major social assistance benefits on the national level, the civil disability pension (pensione di invalidità civile) and the social pension (pensione sociale), persistently amounts only to about $3-4 \%$ of total social spending, according to the Bank of Italy. At the territorial level, data from the Italian National Institute of Statistics indicate standards and criteria for access to social assistance differ greatly among regions and municipalities (Lalioti, 2013: 59-61).

This article draws on personal communications, parliamentary archives and secondary sources to record the story of the Italian GMI experience, especially the story of the experimental national GMI in the late 1990s and the early 2000s. In the absence of 'functional equivalents', above all of a coherent and inclusive social safety net of last resort, and given relatively high poverty ${ }^{3}$, the history of the GMI experiment is striking. An actor-centred approach is employed, focusing mainly on governmental actors, while also acknowledging the policy effects of actions (or inactions) by other key players, such as organized labour and religious organizations. From the viewpoint of political economy, GMI beneficiaries are outsiders with limited political representation, forced to rely on other actors to promote their interests (Huber and Stephens, 2001: 18).

\footnotetext{
${ }^{1}$ At the time of writing.

${ }^{2}$ According to Eurostat data for 2011, spending on old-age and survivors in Italy equalled $57.06 \%$ of total public benefits, well above the EU-28 average of $43.8 \%$.

${ }^{3}$ In 2015 the percentage of total population at risk of poverty in Italy equalled $19.9 \%$. The EU-28 average was $17.3 \%$.
} 
Policy actors' attitudes towards GMI are here assumed to reflect the internal dynamics of given time periods and specific national contexts. Exogenous influences on domestic welfare agendas, such as from 'soft-law' instruments like European recommendations, are relatively mild. Innovations and changes in welfare policy do not follow deterministically, not even from extensive economic developments such as those linked to severe crises (Maino and Neri, 2012: 117). Influences, innovations and changes all depend on discretion, i.e. the interests and ideological preferences of domestic policy actors.

This article aspires to contribute to studies on the Italian GMI experience such as those by Benassi and Mingione (2003), Ranci Ortigosa (2007a), Sacchi (2007), and Madama, Jessoula and Natili (2014). The following sections argue that the early demise of the experimental scheme in the early 2000s followed from a relatively weak support base for a national GMI, in conjunction with the dominance of northern interests at the ministry responsible for the design and implementation of a scheme that mainly benefited the poorer south. The crisis period since 2008 has seen a more intense debate, as national GMI has met support among old and new policy actors. The concluding section synthesizes the main lessons to be learned from the analysis.

\section{First steps towards a GMI}

The coming to power of the Prodi centre-left coalition in May 1996 raised hopes for policy changes that would integrate the weakest socio-economic strata and strengthen the country's potential for a stable European future. The context was set partly by EEC initiatives calling for policy innovation, such as the 1992 recommendations 92/441/EEC and 92/442/EEC, by a broad need to conform with EEC-imposed macroeconomic standards, and by Italy's own deep political crisis. Changing the scenery in social assistance policy was a means of approaching these targets, also helping Prodi to raise his coalition's profile as a modernizing government.

Prodi in January 1997 appointed the expert Onofri Commission, tasked with assessing whether ambitious goals for welfare system reform were compatible with macroeconomic adjustments underway in preparation for European Monetary Union (personal communication with commission chair Paolo Onofri, 11 February 2012). The commission proposed a consistent reform strategy that would include 
institutionalization of a national $\mathrm{GMI}^{4}$ (Commissione per l'analisi delle compatibilitá macroeconomiche della spesa sociale, 1997). The idea was advertised both as a means of facilitating labour market integration for outsiders (Carpo, 1997), and of reducing Italy's high child poverty rates (personal communication with Livia Turco, minister in both Prodi governments, 15 March 2012).

Despite the publicized benefits, the proposal of a permanent national GMI met with variant responses from political parties and labour confederations, from approval to scepticism to complete rejection. Members of the moderate centre and leftist parties in Prodi's Olive Tree coalition, such as Alberta de Simone and Franco Chiusoli from the Democrats of the Left (Democratici di Sinistra, DS), welcomed the scheme as a significant contribution to the Italian welfare state (Camera dei Deputati, 1997b: 34, 96, 129-130). Speaking for the centre-right Pole for Freedoms (Polo per le Libertà), Luca Danese argued that a GMI would be useless if it could not connect recipients with productive activities more obviously than in the centre-left's proposal (Camera dei Deputati, 1997a: 34).

The youth organizations of the Democratic Party of the Left (Partito Democratico della Sinistra, PDS) objected to the charitable aspect of the GMI, instead favouring policies to target job creation. These organizations went further, formulating a proposal underscoring the need for a stronger social insertion component than in the scheme proposed by the Onofri Commission (La Repubblica, 1 February 1997).

The most prominent opponent to GMI, however, was inside the Prodi government itself. Minister of Labour and former Christian Democrat Tiziano Treu compared offering GMI to the young to dispensing methadone (Lupoli, 1997). Likewise, the Communist Refoundation Party (Partito Rifondazione Comunista, PRC) rejected all Onofri Commission proposals as attempts to mask politically reactionary choices with the cold rationality of numbers (La Repubblica, 6 March 1997). According to Vittore Luccio, a collaborator with the PRC's general secretary (personal communication, 4 February 2013), his party also thought acceptance of the Onofri proposals would amount to a retreat from a full defence of workers' rights. To finance GMI, the government intended to abolish the Redundancy Fund (Cassa Integrazione Guadagni, CIG), which was considered symbolic as a protection of

\footnotetext{
${ }^{4}$ The Commission integrated the GMI proposal of the 1995 Commission for Research on Poverty Issues.
} 
workers' rights in general. Replacing CIG with GMI was seen as leaving workers completely unprotected against layoffs.

The unions were hostile or sceptical at best. Bruno Trentin, former leader of the General Confederation of Labour (Confederazione Generale del Lavoro, CGIL) and other prominent CGIL members issued explicit rejections. Likewise, the president of the Italian Confederation of Trade Unions (Confederazione Italiana Sindacati Lavoratori, CISL), Sergio D'Antoni, definitively opposed indiscriminate access to GMI-related measures for youth (La Repubblica, 1 February 1997). CISL General Secretary Raffaele Morese took a somewhat different position, commenting:

The GMI being a social assistance scheme which does not promote job creation does not make it the best policy we (the unions) could imagine... an experimental phase will definitely help, however, in the sense of mitigating the risks of making the GMI permanent... we will see whether it helps beneficiaries get a job... instead of ending up as another sort of social assistance programme (Esposito, 1998, 6).

Objections to GMI and defences of the existing welfare system were related to a general fear of restructuring, given that the national GMI proposal was linked to the gradual abolition of other social assistance categories. Labour confederations feared that a GMI might trigger an attack on unemployment benefits, be used as a minimum wage threshold, or replace active labour market policies. Insofar as GMI typically targets outsiders, it might mean a smaller pie for insiders (Lalioti, 2013: 103-104). Meanwhile Innocenzo Cipolletta, general director of the employers' federation Confindustria, claimed the scheme would function as a disincentive against labour (Il Sole 24 Ore, 5 March 1997).

The religious community displayed two clear trends. First, the church hierarchy took no public stance, following the non-alignment policy embraced by the Vatican through part of the 1990s, and feeling secure after their successful defence in 1988 of the principle of subsidiarity and the resulting consolidation of Catholic religious organizations' role in the social assistance field. This lack of involvement contrasts with areas where the church felt more threatened, for instance in family policy (Lalioti, 2013: 91, 93, 104; Chianura, 1999). Second, however, organizations like Caritas and the Christian Associations of Italian Workers (Associazioni Cristiane Lavoratori Italiani, ACLI) believed GMI aligned with their organizational principles, 
seeing it as a significant step towards recognition of social citizenship for people at society's margins. Caritas' support did not translate into formal advocacy in public documents, however. Francesco Marsico, vice-director of Caritas Italiana (personal communication, 20 March 2012) attributes this to its identity as the pastoral organization of the Catholic Church.

The initial national GMI debate was thus shaped by division in the government, scepticism or hostility from parties, interest groups and labour, and only 'unofficial' support from Catholic grass-roots groups. Given this lack of a strong constituency, let alone a coalition in support, Prodi went ahead with a limited experiment as a way to demonstrate poverty was on the agenda, postponing actual financial and policy decisions until after the experiment.

\section{A 'stillborn' GMI experiment}

Law 449/1997 introduced an experimental GMI at the national level, called a 'Minimum Income for Integration' (Reddito Minimo di Inserimento, RMI). Due to the socio-economic and other criteria used in selecting the 39 participating municipalities, the vast majority of beneficiaries (93\%) were in the country's south (IRS, Fondazione Zancan, and CLES, 2001; Sacchi and Bastagli, 2005: 112). The low cost (about 284 million euros) left the government room to introduce additional social policy measures (La Repubblica, 13 June 1998).

RMI recipients were defined as persons whose income did not exceed the 1998 poverty line of 500,000 lire (258.23 euros) monthly for an individual living alone (Legislative Decree 237/1998, Article 6). The monetary allowance equalled the difference between the poverty line and actual income. The amount was set nationally, without consideration of regional differences in cost of living. Beneficiaries were also expected to participate in customized plans for social integration, such as training courses and care services to be devised locally (Sacchi, 2006: 874-875). RMI provided territorial actors (local governments) with an opportunity to confront extreme poverty, assess the quality of services provided by local managers in the fight against poverty, and increase their popularity at low financial cost.

While criticisms continued, inter alia proving the use of the term 'experiment' ambiguous (Lalioti, 2013, 107-108), the main official reason for the pilot RMI was to 
identify operational difficulties territorial actors faced in providing benefits and managing insertion programmes, thereby testing in different contexts the scheme's effectiveness in overcoming economic need and marginalization (Legislative Decree 237/1998, Article 2). The plan was to evaluate the experiment, then decide whether to convert it into a permanent national programme at the end of 2000. By then the programme had 86,000 recipients. About 220 million euros were spent during the first two years (IRS, Fondazione Zancan, and CLES, 2001; Sacchi and Bastagli, 2005: 117-118), less than one-thousandth of the Italian state's overall social expenditure of 282,617 million euros according to the Bank of Italy (Lalioti, 2013: 106).

The next milestone for the RMI came with the passage of Law 388 (23 December 2000) by the Amato government. Instead of making the RMI permanent, Article 80 extended it two years to 31 December 2002. The second experimental phase was to include 306 municipalities through territorial pacts with the 39 municipalities of the first phase. Introduced by the government as new policies for local development, the pacts meant the majority of municipalities in this second phase were again in the south. The use of these networks to enact RMI was deemed a unique opportunity for institutional collaboration among territorial actors (Ministero della Solidarietà Sociale, 2007: 19, 122).

Why did the Amato centre-left government decide on an extension instead of making the RMI permanent? The answer lies in the political situation at the time, with a political environment still resembling that during the launch of the first phase under the Prodi government. According to the scientific director and president emeritus of the Institute for Social Research, Emanuele Ranci Ortigosa (personal communication, 25 January 2012), who was responsible for evaluating the Italian GMI experiment:

Centre-left parties opted to prioritize alternative policies, particularly the integration of minimum pensions, rather than using the same resources for a reform that would introduce GMI... Labour confederations exerted similar pressures. They were reluctant to accept a dilution of the Italian welfare system's contributory character, which secured for them a direct interventionist role in the system, for the sake of a more universalistic system.

Italian media busily publicized the gap between the needs and capacities of territorial actors in the north as against the south (Magni and Sala, 2000; Sala, 2000; Arachi, 2002). This should be viewed within the broader fracture between north and 
south, a long-standing historical phenomenon that widened during the first phase of industrial development in the early twentieth century (Putnam, Leonardi and Nanetti, 1993; Fargion, 2005: 138).

While the government could not easily ignore these factors and make the scheme permanent, it should also be recalled that the decision to extend the experiment came only months before the May 2001 general elections. Under pressure from southern territorial actors, some cadre of the centre-left coalition, mainly from the south and connected with Catholic third-sector organizations, supported the extension of RMI in their electoral districts (Lalioti, 2013: 110-111).

This dissension reflected yet again how fragmentary the scheme's support was. With the centre-left always divided and other key actors sceptical or hostile, it would prove impossible for the politically fragile initiative's few ardent supporters to ensure its survival against future changes in government.

It has furthermore been argued (Sacchi and Bastagli, 2005: 85; Sacchi, 2006: 876) that termination of the GMI experiment was enabled by a 2001 constitutional reform depriving the central government of the power to issue planning instruments in the social assistance field (as Law 328/2000 had provided). After losing regional elections in 2000, Olive Tree adopted more devolution policy to compete with the Northern League (Lega Nord, LN) and undermine the centre-right (Bull and Pasquino, 2007) in the 2001 national elections. In 2000, the Prodi coalition had still emphasized national standards for minimum service levels (the 'essential levels for provisions', Livelli Essenziali delle Prestazioni, Liveas) (La Repubblica, 1 June 2000). The 2001 reform instead made implementation dependent on voluntary compliance from territorial actors. Since the central government had the authority only to define Liveas for the entire country, a national GMI could exist only if included in the Liveas (Sacchi, 2006: 876).

Turco (personal communication, 15 March 2012) disagrees:

The 2001 constitutional reform, specifically Article 117, did not expedite the RMI's abolition. On the contrary, it transformed the RMI into a constitutional right, enabling the central government to guarantee a permanent national RMI through the establishment of the Liveas. If the law was never applied as it should have been, had the Liveas never been established nor the funding cut, is another story. 
The centre-left lost the election of 13 May 2001 to the centre-right 'House of Freedoms' (Casa delle Libertà, CdL) coalition. Although Berlusconi was the new government's unquestioned leader, the Lega Nord, key to winning the election and maintaining the coalition, became a powerful veto player. The Lega was likewise pivotal in the abolition of RMI.

\section{The road to abolition}

In 2001 the centre-right returned to power for the first time since a nine-month period in 1994. At the same time, a trio of independent research centres (IRS, Fondazione Zancan and CLES, 2001) assessed the RMI's first experimental phase. Cadre from Berlusconi's Forza Italia (FI) and the Lega Nord soon showed their disapproval of RMI. Although Naples was among the municipalities that the programme had benefited most, it was denounced as pure welfare dependency by the FI provincial coordinator, Antonio Cuomo, and by the head of FI in the Naples regional council, Francesco Bianco (Fuccillo, 2004).

Lega Nord, increasingly eurosceptic, was even more adamant in its opposition. During the election campaign its cadre, sounding like libertarians, claimed the free market offered effective protection to citizens and argued that public funds should be redirected from welfare benefits ('state handouts' that hindered economic development) to initiatives against unemployment (Greene, 2003:199). RMI reminded them of 1993, when protests broke out in northern Italy against a new minimum tax opponents believed would drain northern resources to support a dependent south (Gold, 2003: 94).

Lega Nord had long accused southern Italy of developing 'a welfaredependent culture addicted to the guarantees of the Italian bureaucracy' (Bossi and Vimercati, 1993: 42), diverting federal resources that might otherwise have been invested in the private sector to foster growth. Welfare benefits for unworthy recipients in southern Italy would cause further deterioration of a country already operating at two speeds, 'that of the producer... and that of the parasites' (Bossi and Vimercati, 1993: 20).

Thus it came as no surprise when the government downplayed evaluators' positive remarks about the first RMI phase. The evaluators found that the scheme 
mobilized territorial actors and encouraged inter-institutional cooperation and mutual learning within the public sector, as well as between the public and non-profit sectors (Saraceno, 2006: 105). In a similar vein, the 2001 National Action Plan for Social Inclusion, officially presented in June, referred to the experiment as one of the country's best practical implementations of an anti-poverty programme (Ministero del Lavoro e delle Politiche Sociali, 2001: 58).

The new government instead publicized and exaggerated the experiment's negative aspects, painting an image of how well the developed, effective, productive north performed in comparison to the underdeveloped, ineffective and 'idle' south. The government stressed that the vast majority of RMI recipients lived in the south, where only a quarter participated in the scheme's social inclusion programmes even two years after introduction; meanwhile, almost two-thirds of RMI beneficiaries in the north and a majority of those in central Italy were recorded as taking part in such programmes (Sacchi and Bastagli, 2005: 120).

Having established this tactic of blaming the south, in July 2002 the government entered a so-called Pact for Italy (Patto per l'Italia) along with two of the country's trade union associations, CISL and the Italian Labour Union (Unione Italiana del Lavoro, UIL). CGIL refused to sign, regarding the pact chiefly as another government attempt to avoid dealing directly with the major labour confederations. During this time the centre-right sought to distance itself from consultation (concertazione) and move to a sui generis social dialogue that required no agreement between government and other social actors (Pulignano, 2003: 6).

Under the Pact for Italy (Point 2.7), the RMI experiment proved 'the unfeasibility of legally identifying persons with the right to enter this social safety net', so that it was necessary to create 'a new instrument' called the 'Income of Last Resort' (Reddito di Ultima Istanza, RUI; see Ministero del Lavoro e delle Politiche Sociali, 2002; Strati, 2009: 5). The government intended provisions modelled on GMI to exist only as voluntary, territorial programmes. Only the most financially powerful actors, concentrated in the north, were likely to possess resources for such schemes.

Thus the positive evaluation reports and the 2001 National Action Plan for Social Inclusion came to naught. Lega Nord's Roberto Maroni, minister of labour and social policy under Berlusconi, became chief architect of RUI as a replacement for national RMI. Maroni denounced RMI as a failure, blaming the south and stating in 2002: 'The objectives of the RMI were not accomplished... dangerous distortions 
occurred, especially in the south, along with a return to practices that have nothing to do with combating irregular work, fighting social exclusion, or promoting reintegration into the labour market'. He further denounced existing safety net arrangements as 'unfair and inefficient... children of the previous government', which he described as 'a prisoner of extreme views fostering a culture of dependency'.

Maroni's attitude conforms with Lega Nord's ideological stance, in which solidarity is restricted towards northerners and directed against those considered to be strangers, i.e. southerners. The Lega's priority was to represent northern interests. According to Ranci Ortigosa (personal communication, 25 January 2012), poverty is mainly present in the south, and the resources allocated for RMI were paid largely to southern municipalities. With political regionalism at its height, Lega Nord exploited growing discontent with the huge share of public expenditure fruitlessly earmarked for the south, calling RMI another example of the Italian state's 'southernization', an imposition of deviant 'southern' practices as opposed to 'northern' ones (Bull, 1994: 75).

While Maroni made allegations, the government attacked RMI systematically. According to Chiara Saraceno (personal communication, 3 February 2011), former head of the Commission for Research on Poverty Issues and Social Exclusion and also an advisor to Livia Turco, the first Prodi government's minister of social solidarity:

...Part of the official documentation disappeared... not only by the minister's decision but also the head of department who passed from one minister to the other, as well of functionaries who monitored the experiment (and most likely wanted to please the new minister). The Poverty Commission I chaired was congealed, offices closed, archives including those of the experiment dispersed. When I managed, threatening to go public, to de-freeze the Commission some months later, in order to complete the annual poverty report, even the computer files were no longer there.

The political dominance of northern interests at the Ministry of Labour and Social Policy is also manifest in Fabrizio Spinnato's words. Asked for the Lega's position on RMI, Spinnato, in charge of social affairs at Lega Nord's Padania office, pointed to public, government documents such as the Pact for Italy (Point 2.7) and the White Book on Welfare (pp. 37-38, on which more below) (personal communication, 
18 January 2012). Nearly a year after the first RMI evaluation report appeared and despite continuing leaks to the media concerning the south's problematic performance, the report had not publicized or discussed in parliament as the law required (Lalioti, 2013: 115).

Thus the end was near, given a meagre support base for RMI, the antisouthern Lega's control of the relevant ministry, and the poorer south's gains from the scheme.

\section{Alea iacta est; allegations and truths}

Law 289/2002 (27 December) allocated no further resources for RMI. The White Book on Welfare (February 2003) reiterated negative comments on the scheme (Ministero del Lavoro e delle Politiche Sociali, 2003a: 37) and proposed introduction of RUI.

Reference to problems in implementing the second RMI phase was again made in the second National Action Plan for Social Inclusion (July 2003), now drafted exclusively by the centre-right. These were attributed to the incapacity of territorial actors, i.e. local governments, to design and execute the scheme's social inclusion component, as well as to the deficiencies of the Italian welfare system (Ministero del Lavoro e delle Politiche Sociali, 2003b: 27-28). In September 2003, Maroni again asserted RMI was 'an expensive and inefficient mechanism' ( $L a$ Repubblica, 19 September 2003).

Putatively high costs and ineffectiveness became the centre-right's official reasons for abolishing RMI. Yet neither was justified by the facts. Estimates for the annual cost of implementing national-level RMI ranged from two billion (Guerra and Toso, 2004: 2) to three billion euros (Sestito and Nigro, 2004). Even the latter represented just $0.23 \%$ of national GDP in 2003. The cost of civil disability pensions in the same year amounted to 10.5 billion euros, approximately $0.8 \%$ of Italy's GDP (Ministero dell'Economia e delle Finanze, 2004).

For many southern municipalities, the RMI experiment was the first experience of a modern income support founded on the concept of citizenship as a right rather than a privilege (as had been the norm). The admitted difficulties in managing demand for associated services in some cases triggered clientelism and fraud, but these were isolated incidents (Benassi and Mingione, 2003: 43). Local 
variability in policy outcomes is, moreover, manifest even in systems believed superior to Italy's, for instance in France (Mingione, Oberti and Pereirinha, 2002: 6177), without however being used as an excuse to abolish GMI.

Finally, the experimental phase had been presented as a necessity for testing feasibility, locating weaknesses, and identifying corrective measures. The decision to cancel RMI precisely because of the expected unequal institutional performances among different territorial actors contradicts this. As Ranci Ortigosa (personal communication, 25 January 2012) asserts:

The overall outcome was not discouraging. Especially the evaluation helped to articulate a clear set of guidelines for addressing the difficulties that arose within an appropriate time span. Thus, I do not think that there were any substantive reasons for the centre-left not to support the scheme or for the centre-right to abolish it.

As supposed evidence of failure, the government and some journalists even pointed to the relatively high percentage of families exiting the RMI. They tended not to mention that this was because they had overcome the initial state of need (Sacchi, 2006: 876). The second RMI evaluation report, this time conducted by four research centres, showed that the highest exit percentages were in municipalities exhibiting the lowest rates of unemployment, effectively arguing for the success of the RMI (Ministero della Solidarietà Sociale, 2007: 102 -104).

For the vast majority of municipalities, RMI opened the way for rationalizing municipal services and integrating them into wider regional administrative schemes, also bringing about improvements in institutional and administrative capacities. Faced with zero or suspiciously low declared income, for example, several municipal governments assessed the living standards of RMI beneficiaries by visiting claimants' homes to scrutinize their lifestyle, or requiring recipients to participate in a social integration programme at strategic times during the working day so as to prevent them from having another job in the informal economy (Sacchi and Bastagli, 2005: 121125).

In short, the evidence does not support that high costs and/or ineffectiveness were the real reasons for the RMI's abolition. A more credible explanation lies in domestic politics and the fragmented support or hostility of powerful constituencies 
and interest groups. This was reflected in the almost complete absence of protests against abolition.

For example, reactions from the labour confederations were mixed. A few Catholic grassroots organizations that had been involved in RMI activation measures, including Caritas, did express opposition when the White Book was presented to social policy actors by Maroni and the secretary of social affairs, the Forza deputy Grazia Sestini, on 20 February 2003. That opposition never took the form of more overt protest, however (Lalioti, 2013: 120).

The southern-dominated leadership of the National Association of Italian Communities (Associazione Nazionale Comuni Italiani, ANCI) was among the few representatives of territorial actors to organize a protest against abolition. The ANCI National Council was headed by the mayor of Foggia (Apulia) in southern Italy, Paolo Agostinacchio. He laid the blame for abolition on two members of Forza, Antonio Azzollini, chairman of the Permanent Parliamentary Committee on the Budget, and Alberto Zorzoli, the committee's secretary (Petrini, 2002).

As Ferrera (2003:635) put it, GMI schemes represent 'a sphere of asymmetrical solidarity, in other words public support based purely on considerations of need, which presupposes strong ties of we-ness'. These ties were fatally lacking.

\section{Post-RMI debate about a national-level GMI}

Advertised by Maroni as an 'alternative' to the RMI 'failure' (despite the lack of a social inclusion component), the RUI scheme met with the same inglorious finale: it was never implemented. Under Law 350/2003 (Article 3) and the 2003-2005 National Action Plan for Social Inclusion, the central government was required to cofund RUI in regions that decided to adopt it. RUI would cover up to $2.7 \%$ of Italian households with an average of 2,925 euros per household, while the funding needed was approximately 1.67 billion euros (Sestito, 2004: 3-4).

The Ministry of Labour and Social Policy, however, avoided having the 2003 law state explicitly that RUI would be part of the Liveas that the government was supposed to ensure, or that it was exclusively regional (Strati, 2009: 5). Again, in the absence of these clarifications RUI paved the way for the central government to fund those territorial actors most able to implement the scheme, in other words, the wealthier, northern regions. 
A final attack on RUI came in late 2004 from the judiciary. On a filing from several territorial actors who claimed the government's initiative infringed upon their autonomy in social assistance policy, the Constitutional Court ruled that Rome had no authority to co-finance RUI schemes. The court claimed that the 2001 constitutional reform gave the government authority only to define Liveas (Sacchi, 2006: 876-877).

The ruling annulled the provision (Law 350/2003) allowing the central government to co-finance RUI schemes. The centre-right established no other fund to finance the measure, and the 2005 budget law (Law 311/2004) no longer made any reference to RUI. Furthermore, the only place that implemented RUI, the Rovigo municipality in the Veneto region, had made access contingent on the number of children in a family, the absence of a parent, the presence of elderly or disabled relatives, and so forth (Strati, 2009: 5). Many of those most in need were barred, raising further doubts whether RUI could ever have constituted a real alternative to RMI.

That a large portion of policy actors had little interest in establishing social rights shared by all Italian citizens was again reflected in the 2005 constitutional reform, which further strengthened regional autonomy, providing a solid constitutional basis for both fragmentation and local federalism (Legislative Decree 2544/2005). This worked against development of a national shared framework in the social assistance policy field, including GMI.

During the second Prodi government, from April 2006 to May 2008, the economics and finance plan for 2007-2011 confirmed an intent to reconsider RMI. However, this would first require 'evaluating the effectiveness of the measure in relation to the financial costs that its implementation might impose collectively' (Ministero dell'Economia e delle Finanze, 2006: 140).

Evidence from both the 1998 RMI experiment and more recent local experiences shows it would be relatively easy to design GMI so as to minimize fraud (Lalioti, 2013: 123). Moreover, scholars such as Monti and Pellizzari (2008) have indicated that a reasonably generous version of the scheme is financially viable. They estimated a total annual cost of 6.6 billion euros, about $0.5 \%$ of Italian GDP, to cover participation of $8 \%$ of Italian households. This calculation was based on a singleperson income threshold of 400 euros monthly. They contend viability would be guaranteed, especially if the monetary transfer's nominal value was allowed to vary 
according to differences in the cost of living around the country. Most GMI recipients did live in the south, where costs are typically lower than in the rest of the country.

Hinting instead at the scheme's putative (unknown and high) financial costs, the painstakingly worded 2006 plan for fiscal 2007-2011 subtly bespoke the centreleft's lack of will to re-introduce RMI. This document's GMI talk put the poor back on the agenda symbolically, but the centre-left coalition still lacked a strong faction in support.

According to Turco (personal communication, 15 March 2012), Paolo Ferrero, social solidarity minister under the 2006-2008 Prodi government and a PRC member, had a different vision of social policy. Under Ferrero's direction the social policy agenda paid more attention to benefiting precarious workers, which Ferrero considered to be the solution to poverty (Lalioti, 2013: 124). Priority was also given to favouring pensioners; the government forged an agreement with labour unions to avoid a three-year increase in the retirement age, with a serious impact on the whole pension system (Madama, Jessoula and Natili, 2014: 12).

The laws for fiscal year 2008 (222/2007 and 244/2007) allocated no funding for RMI and the government did not re-introduce the scheme. In his own defence, however, Ferrero points to the early fall of the second Prodi government as the sole reason for inaction on the RMI front (personal communication with Vittore Luccio, 31 January 2012).

In the immediate pre-crisis years the major labour confederations, especially CGIL, had adopted a theoretically more positive attitude towards a national GMI. According to Vera Lamonica, a CGIL national secretary (personal communication, 13 February 2012), her confederation strongly favours GMI's combination of income support with programmes for social inclusion and employment of those who are eligible. CGIL on 4 June 2007 held a conference on GMI in Rome, with participation also from CISL and UIL. On behalf of CGIL, Achille Passoni opened his presentation with the question, 'Who is representing the poor?' (Ranci Ortigosa, 2007b: 1).

According to Eurostat data, the proportion of working poor in Italy increased from $8.8 \%$ in 2005 to $9.8 \%$ in 2007 , a non-negligible rise of more than $10 \%$ in two years. This context arguably makes GMI a more attractive device for improving the income and living conditions of individuals who constituted the core of the union movement (Lalioti, 2013: 124-125). 
The post-2008 crisis hit the Italian welfare state hard, causing severe cuts in health, social services and family policies and accelerated privatization of the pension system (Maino and Neri, 2012). Against this backdrop, despite Italian labour's claims of support for GMI, 'insiders', such as members of trade unions, may be incentivized to revert to traditional priorities and defend the status quo. The slice of the pie for insiders is shrinking. Policy measures that benefit the so-called working poor and extreme outsiders (those who usually form the GMI clientele) put a further squeeze on resources for the vast majority of those represented by the trade unions. Despite appearances to the contrary, unions (many of whose members are pensioners) are not ready in practice to support a re-balancing of social expenditures so as to make room for GMI (see also Ciccarelli, 2013 on the 'lavorismo' of the Italian labour movement).

All the same, the national GMI debate has revived. Social policy issues are increasingly salient for political party competition. GMI seems to have found support from both old and new policy actors. The old actors include Caritas. For instance, Caritas of Lombardy, with the Catholic University of the Sacred Heart in Milan, prepared a study on 'Independence Income' (Reddito di Autonomia) (personal communications, Francesco Marsico, 20 March 2012; and Pierluigi Dovis, in charge of the regional commission of Caritas Turin, 2 March 2012; see also Caritas Italiana, 2013: 38).

Among the new proponents of GMI are members of the Democratic Party (Partito Democratico, PD), which arose in 2007 from a merger of various left-wing and centrist parties; prominent ministers of the Monti cabinet; the Basic Income Association of Italy (BIN-Italia), formed in 2008; Nichi Vendola's Left, Ecology, Freedom (Sinistra Ecologia Libertà, SEL), founded in 2009; and Beppe Grillo's Five Star Movement (Movimento 5 Stelle, M5S), likewise launched that year.

The reasons behind these actors' willingness to promote a GMI mechanism are different. For example, Elsa Fornero, minister of labour, social policy and gender equality in the Mario Monti cabinet of November 2011 to April 2013 envisioned GMI as part of structural reform in labour policy to target an increase in so-called 'flexicurity' (Foschi, 2011). By contrast, BIN-Italia viewed a GMI as a first step towards the establishment and implementation of a Basic Income.

More recently, Matteo Renzi, who became secretary of the PD in December 2013 and prime minister in February 2014, like his predecessors in the party and government, Bersani and Letta respectively, invoked the need for a guaranteed safety 
net. Pier Carlo Padoan, Renzi's economics minister, is one of the government ministers that has several times mentioned that GMI should be a consideration for the future. Furthermore, among other initiatives, in 2015-2016, the National Institute of Social Welfare (Istituto Nazionale della Previdenza Sociale, INPS) drafted a proposal for the reform of the pension system that included a GMI for those over the age of 55 who were living in extreme poverty.

Is Italy closer to the establishment of a GMI? The future months may show whether the country will remain one of the very few European countries lacking a national GMI. Interestingly, some argue that the chances for a national guaranteed safety net in Italy depend on the success of other anti-poverty policies (Madama, Jessoula, and Natili, 2014: 15-16). Nonetheless, whether Italy will see a national GMI apparently also rests on the interests and preferences of major policy actors who traditionally respond to the pleas of the most powerful constituencies and interest groups, often at the expense of outsiders. A redistributive reform to include outsiders is not considered necessary, even given the crisis (Maino and Neri, 2012). Endogenous dynamics appear, once again, to be more influential than external constraints.

Onofri's comment (personal communication, 11 February 2012), when asked why his commission promoted a 'selective universalism' instead of a more 'universalistic' model of social assistance, highlights another dimension of these dynamics: beyond the importance of budgetary constraints, Italian public opinion generally does not give much value to citizenship rights. Provisions based solely on financial need are not widely accepted.

According to a scientific survey of social media by the "Voices from the Blogs' group at the State University of Milan, only $6.8 \%$ of individuals' opinions sampled online urged the Letta government to implement income support for families in any form, including establishment of a GMI (La Repubblica, 14 May 2013). The leading request instead was for government intervention in the labour market, with $23.2 \%$ of the sample in favour. A survey conducted by an Italian market research company $^{5}$ in January 2014 likewise showed just 6\% of the sample favouring introduction of a GMI as a national priority, as opposed to $46 \%$ who prioritize labour reform (see also Vis, van Kersbergen and Hylands, 2012: 8, 10).

\footnotetext{
${ }^{5}$ The Milan-based Lorien Consulting S.R.L.
} 
Old habits and interests are certainly too strong to die...

\section{Conclusions}

The twisted history of the RMI highlights a lack of political will within the centre-left, rejection from the centre-right, and the absence of a strong, coherent domestic coalition to promote establishment of a national GMI. The centre-left originally introduced the RMI but was divided about it. The centre-right was hostile, largely regarding GMI as benefiting the south at the expense of the north.

Trade union confederations were unprepared to accept restructuring of the entire welfare system for the sake of a permanent national GMI. The ecclesiastical hierarchy, secure in their institutional role in the social assistance field and at that time loyal to a policy of non-alignment, adopted no public stance. Catholic grassroots organizations were among the few to support the scheme because it fit the citizenship model they envisioned. This did not translate into formal advocacy in the public record, however, due to these organizations' 'pastoral' role.

Given a meagre support base, RMI was extremely vulnerable to a change of government. With Lega Nord as Berlusconi's indispensable ally at the time, RMI became a symbol for the danger the Italian state would be 'southernized', leading to the experimental scheme's early demise.

In more recent years, the impacts of the crisis, including increasing salience of social issues in elections, appear to have revived political parties' interest in national GMI, in theory. To 'old' proponents of the scheme such as Caritas, one may now add new formations such as the PD (at least parts of it), SEL, Grillo's M5S, or associations such as BIN-Italia. Against this backdrop, a recent proposal of reform of the pension system promises, inter alia, a GMI for people over the age of 55 who are living in extreme poverty. In a context characterized by the Italian public opinion's preference for other policies, the future months may thus show whether a national GMI mechanism will be established in Italy; at a time when such a scheme is more needed than ever.

\section{Indicative bibliography}

Arachi, Al. 2002. "Controlli nelle case e ispettori in fabbrica. Così si può prevenire." Corriere della Sera, June 9. 
Benassi, D., and En. Mingione. 2003. "Testing the 'Reddito Minimo di Inserimento' in the Italian Welfare System." In Minimum Income Schemes in Europe, edited by G. Standing, 105-156. Geneva: ILO.

Bossi, Um. and D. Vimercati. 1993. La rivoluzione. La Lega: storie e idee. Milano: Sperling \& Kupfer.

Bull, An. 1994. "Regionalism in Italy." In Regionalism in Europe. Regional Aspirations in the Europe of the 1990s, edited by P. Wagstaff, 68-83. Oxford: Intellect.

Bull, M. and G. Pasquino. 2007. “A Long Quest in Vain: Institutional Reforms in Italy." West European Politics 30(4): 670-691.

Camera dei Deputati. 1997a. Discussione di legge finanziaria (A.C. 4355). December 9.

Camera dei Deputati. 1997b. Discussione di legge finanziaria (A.C. 4355). December 10.

Caritas Italiana. 2013. Rapporto 2012 sulla povertà e l'esclusione sociale in Italia. I Ripartenti. Povertà chroniche e inedite. Percorsi di risalita nella stagione della crisi. Roma: Caritas Italiana.

Carpo, S. 1997. Proposal of Reform of the Welfare State. European Industrial Relations Observatory On-Line. March 28.

Chianura, C. 1999. "Turco: Rispetto per il Papa ma no alle interferenze." $L a$ Repubblica, November 1.

Commissione per l'analisi delle compatibilità macroeconomiche della spesa sociale. 1997. Relazione finale. Roma: Presidenza del Consiglio dei Ministri.

Esposito, M.. 1998. “Arriva l'assegno di povertà - Sussidio di 500mila lire al mese.” La Repubblica, May 1.

Fargion, V. 2005. From the Southern to the Northern Question: Territorial and Social Politics in Italy. In The Territorial Politics of Welfare, edited by N. McEwen and L. Moreno, 127-147. London: Routledge.

Ferrera, M. 2003. "European Integration and National Social Citizenship." Comparative Political Studies 36(6): 611-652.

Foschi, P. 2011. "Il piano della Fornero: 'Nuovo' articolo 18 e reddito minimo." Corriere della Sera, December 12.

Fuccillo, R. 2004. "Povertà, aiuti agli immigrati.” La Repubblica, January 29. 
Gold, Th. 2003. The Lega Nord and Contemporary Politics in Italy. New York: Palgrave Macmillan.

Greene, M. 2003. "Right-Wing Movements in the EU: A Case-Study of the Austrian Freedom Party and the Lega Nord.” In The Dollfuss/Schuschnigg Era in Austria: A Reassessment, edited by G. Bischof, An. Pelinka, and Al. Lassner, 187-211. New Brunswick, New Jersey: Transaction Publishers.

Guerra, M. C. and St. Toso. 2004. "Il nome non fa il reddito." La Voce, May 6.

Huber, Ev. and J. Stephens. 2001. Development and Crisis of the Welfare State: Parties and Policies in Global Markets. Chicago: University of Chicago Press.

IRS, Fondazione Zancan, and CLES. 2001. Valutazione della sperimentazione dell'instituto del reddito minimo di inserimento: principali risultati $e$ indicazioni di svillupo. Unpublished Manuscript.

Kazepov, Y. 2011. "L'assistenza sociale in Italia nel confronto Europeo: Tra residualità, innovazione e un futuro incerto." In Il Welfare in Italia, edited by Ug. Ascoli, 103-145. Bologna: Il Mulino.

Lalioti, V. 2013. Social Assistance Outcomes in Southern Europe: An Actor-Centred Approach. Doctoral Thesis, University of Oxford.

Lupoli, An. 1997. "Treu contro il minimo vitale. Dato a tutti è metadone." La Repubblica, March 2.

Madama, Il., M. Jessoula, and M. Natili. 2014. "Minimum Income: The Italian Trajectory-One, No One and One Hundred Thousand Minimum Income Schemes."Working Paper-LPF n. 1. Torino: Centro Einaudi.

Magni, V. and Al. Sala. 2000. "Rapinata a ceffoni da una baby gang." Corriere della Sera, March 21.

Maino, Fr. and St. Neri. 2012. "Explaining Welfare Reforms in Italy between Economy and Politics: External Constraints and Endogenous Dynamics.” In The Times They Are Changing?: Crisis and the Welfare State, edited by B. Greve, 117-136. Oxford: Wiley-Blackwell.

Maroni, R. 2002. "Maroni, niente assistenzialismo per la crisi dell'auto." La Repubblica, October 16.

Matsaganis, M. 2013. "The Guaranteed Minimum Income and its Role in Dealing with the New Social Issue." In Guaranteed Minimum Income: Approaches and Proposals in View of the Pilot Implementation of the Scheme, edited by 
the National Institute of Labour and Human Resources, 10-27. Athens: National Institute of Labour and Human Resources [in Greek].

Mingione, En., M. Oberti, and J. Pereirinha. 2002. "Cities as Local Systems." In Social Assistance Dynamics in Europe, edited by C. Saraceno, 35-79. Bristol: Policy Press.

Ministero dell'Economia e delle Finanze. 2004. Relazione generale sulla situazione economica del paese-2003. Roma: Instituto poligrafico e zecca dello stato.

Ministero dell'Economia e delle Finanze. 2006. Documento di programmazione economico-finanziaria. Roma: Ministero dell'economia e delle finanze.

Ministero del Lavoro e delle Politiche Sociali. 2001. Piano nazionale per l' inclusione. Roma: Ministero del lavoro e delle politiche sociali.

Ministero del Lavoro e delle Politiche Sociali. 2002. Patto per l'Italia, Roma.

Ministero del Lavoro e delle Politiche Sociali. 2003a. Libro bianco sul welfare: Proposte per una società dinamica e solidale. Roma.

Ministero del Lavoro e delle Politiche Sociali. 2003b. Piano di azione nazionale contro la povertà e l'esclusione sociale 2003-2005, Roma.

Ministero della Solidarietà Sociale. 2007. Relazione al Parlamento. Attuazione della sperimentazione del reddito minimo di inserimento e risultati conseguiti. Roma: Direzione generale per la gestione del fondo nazionale per le politiche sociali e monitoraggio della spesa sociale.

Monti, P. and M. Pellizzari. 2008. "Implementing a Guaranteed Minimum Income in Italy: An Empirical Analysis of Costs and Political Feasibility." Paper presented at ESPAnet-Italia, Ancona, November 6-8.

Petrini, R. 2002. "Gli enti locali contro la manovra. A rischio i servizi ai cittadini.” $L a$ Repubblica, December 5.

Pulignano, V. 2003. "Union Struggle and the Crisis of Industrial Relations in Italy." Capital \& Class 79: 1-7.

Putnam, R., R. Leonardi, and R. Nanetti. 1993. Making Democracy Work: Civic Traditions in Modern Italy. Princeton: Princeton University Press.

Ranci Ortigosa, Em. 2007a. "La riforma del welfare. Dieci anni dopo la Commissione Onofri. Il reddito minimo di inserimento." ASTRID-Fondazione Ermanno Gorrieri-IRS, pp. 1-16.

Ranci Ortigosa, Em. 2007b. "I poveri, chi li rappresenta?" Prospettive Sociali e Sanitarie 12: 1-2. 
Sacchi, St. 2006. "Che fine ha fatto il reddito minimo di inserimento?." Il Mulino 5: $870-880$.

Sacchi, St. 2007. "L'esperienza del reddito minimo di inserimento." In Povertà e benessere. Una geographia delle disuguaglianze in Italia, edited by An. Brandolini and Ch. Saraceno, 423-448. Bologna: Il Mulino.

Sacchi, St. and Fr. Bastagli 2005. "Italy-Striving Uphill But Stopping Halfway. The Troubled Journey of the Experimental Minimum Insertion Income." In Welfare State Reform in Southern Europe. Fighting Poverty and Social Exclusion in Italy, Spain, Portugal and Greece, edited by M. Ferrera, 84-140. London: Routledge/EUI Studies in the Political Economy of Welfare.

Sala, Al. 2000. "Orfani dell'industria a rischio povertà." Corriere della Sera, March 1.

Sestito, P. 2004. "Se il reddito è di ultima istanza." La Voce, May 6.

Sestito, P. and V. Nigro. 2004. "La sensibilità alle regole di accesso della spesa Aggregata e della Composizione dei beneficiari nel sostegno al reddito di ultima istanza: alcune valutazioni." Mimeo.

Strati, F. 2009. Italy. Minimum Income Schemes. A Study of National Policies (on behalf of the European Commission, DG Employment, Social Affairs and Equal Opportunities). Brussels.

Vis, B., K. van Kersbergen, and Th. Hylands. 2012. "To What Extent Did the Financial Crisis Intensify the Pressure to Reform the Welfare State?." In The Times They Are Changing?: Crisis and the Welfare State, edited by B. Greve, 7-22. Oxford: Wiley-Blackwell. 